\title{
Patterns of insecticide resistance and knock down resistance $(k d r)$ in malaria vectors $A n$. arabiensis, An. coluzzii and An. gambiae from sympatric areas in Senegal
}

El Hadji Amadou Niang ${ }^{1,2}$, Lassana Konaté ${ }^{2}$, Mawlouth Diallo', Ousmane Faye ${ }^{2}$ and Ibrahima Dia ${ }^{1 *}$

\begin{abstract}
Background: Malaria vector control in Africa relies on insecticides targeting adult mosquito vectors via insecticide treated nets or indoor residual spraying. Despite the proven efficacy of these strategies, the emergence and rapid rise in insecticide resistance in malaria vectors raises many concerns about their sustainability. Therefore, the monitoring of insecticide resistance is essential for resistance management strategies implementation. We investigated the $k d r$ mutation frequencies in 20 sympatric sites of An. arabiensis Patton, An. coluzzii Coetzee \& Wilkerson and An. gambiae Giles and its importance in malaria vector control by evaluating the susceptibility to insecticides in four representative sites in Senegal.
\end{abstract}

Methods: Sibling species identification and $k d r$ mutation detection were determined using polymerase chain reaction on mosquitoes collected using pyrethrum sprays collection in 20 sites belonging to two transects with differential insecticide selection pressure. The World Health Organization (WHO) tube test was used to determine phenotypic resistance of An. gambiae s.l. to DDT, deltamethrin, lambdacyholothrin, permethrin, bendiocarb and malathion in four representative sites.

Results: The L1014F kdr mutation was widely distributed and was predominant in An. gambiae in comparison to An. arabiensis and An. coluzzii. The bioassay tests showed a general trend with a resistance to DDT and pyrethroids and a susceptibility to organophosphate and carbamate according to WHO thresholds. For deltamethrin and permethrin, the two most used insecticides, no significant difference were observed either between the two transects or between mortality rates suggesting no differential selection pressures on malaria vectors. The study of the KD times showed similar trends as comparable levels of resistance were observed, the effect being more pronounced for permethrin.

Conclusions: Our study showed a widespread resistance of malaria vectors to DDT and pyrethroids and a widespread distribution of the $1014 \mathrm{~F} \mathrm{kdr}$ allele. These combined observations could suggest the involvement of the $k d r$ mutation. The existence of other resistance mechanisms could not be ruled out as a proportion of mosquitoes did not harbour the $k d r$ allele whereas the populations were fully resistant. The susceptibility to carbamate and organophosphate could be exploited as alternative for insecticide resistance management.

Keywords: Insecticide resistance, kdr resistance, Anopheles arabiensis, Anopheles coluzzii, An. gambiae

\footnotetext{
*Correspondence: dia@pasteur.sn

'Unité d'Entomologie Médicale, Institut Pasteur de Dakar, 36 Avenue Pasteur,

BP 220, Dakar, Sénégal

Full list of author information is available at the end of the article
} 


\section{Background}

Malaria vector control in Africa is based predominately on the use of residual insecticides through indoor residual spray and insecticide treated nets [1]. Both methods have shown to be very effective against Anopheles mosquitoes $[2,3]$. Pyrethroids are considered most suitable for bednets impregnation due to their insecticidal effect, relative safety for human and other mammals and their quick knock-down effect on mosquitoes, whereas other insecticide classes (organophosphates, carbamates and organochlorines) are mainly used for Indoor Residual Spraying [4]. In some contexts, the use of both methods has significantly improved the prevention and control of malaria [3]. However, the development of insecticide resistance has become a serious threat to the effectiveness of these control measures. One of the mechanisms involved in pyrethroid resistance in Anopheles gambiae Giles is caused by target-site insensitivity through a knock-down resistance $(k d r)$ produced by two different points mutation at amino acid position 1014 of the voltage gated sodium channel gene. The first leads to leucine-to-phenylalanine substitution and is widely distributed in West Africa [5] whereas the second was described in East Africa and involves a leucine-to-serine change [6]. To date, the latter is mainly found with the $1014 \mathrm{~F} k d r$ allele and is suspected to be less involved in pyrethroid resistance than the 1014F allele [7, 8]. Within the An. gambiae complex, a sympatric ecological diversification is in progress and has leaded to the emergence of at least two incipient species (the $\mathrm{M}$ and $\mathrm{S}$ molecular forms). These forms repeatedly showed heterogeneous levels of divergence in most parts of Africa [9, 10], and are now recognised as separate species - An. coluzzii Coetzee \& Wilkerson and
An. gambiae respectively for $\mathrm{M}$ and $\mathrm{S}$ forms [11]. In their "far west" African distribution, genetic isolation was observed along the Senegambian coasts [12] as well as in inland areas of south-eastern Senegal, where substantial reproductive isolation was evident and further supports the ongoing process of speciation in inland areas [13].

Previous studies have revealed the presence of the $k d r$ mutation in An. gambiae and its absence in An. coluzzii populations even in sympatric areas where the mosquitoes are presumably subjected to similar selection pressures. These observations supported the possibilities of different resistance mechanism in An. coluzzii populations or a restriction in gene flow between the two species [14-17] that could therefore affect the spread of the $k d r$ mutation. Subsequent studies conducted thereafter showed the presence of this mutation in An. coluzzii populations in several sites in Africa. This was first reported in Benin and was attributed to the existence of gene flow from $A n$. gambiae to An. coluzzii rather than the same mutation that occurred in both species [18] and further in Cameroon [19].

Based on the presence of An. arabiensis Patton, An. coluzzii and An. gambiae in sympatric areas in southeastern Senegal, we assessed the $k d r$ frequencies in 20 sites and further studied its importance in terms of vector control by evaluating the susceptibility to insecticides in four representative sites.

\section{Methods}

\section{Study design and study sites}

The study was conducted in the Tambacounda region of southeastern Senegal (Fig. 1) during the rainy seasons, 2010 and 2011, which last from June to October, with a

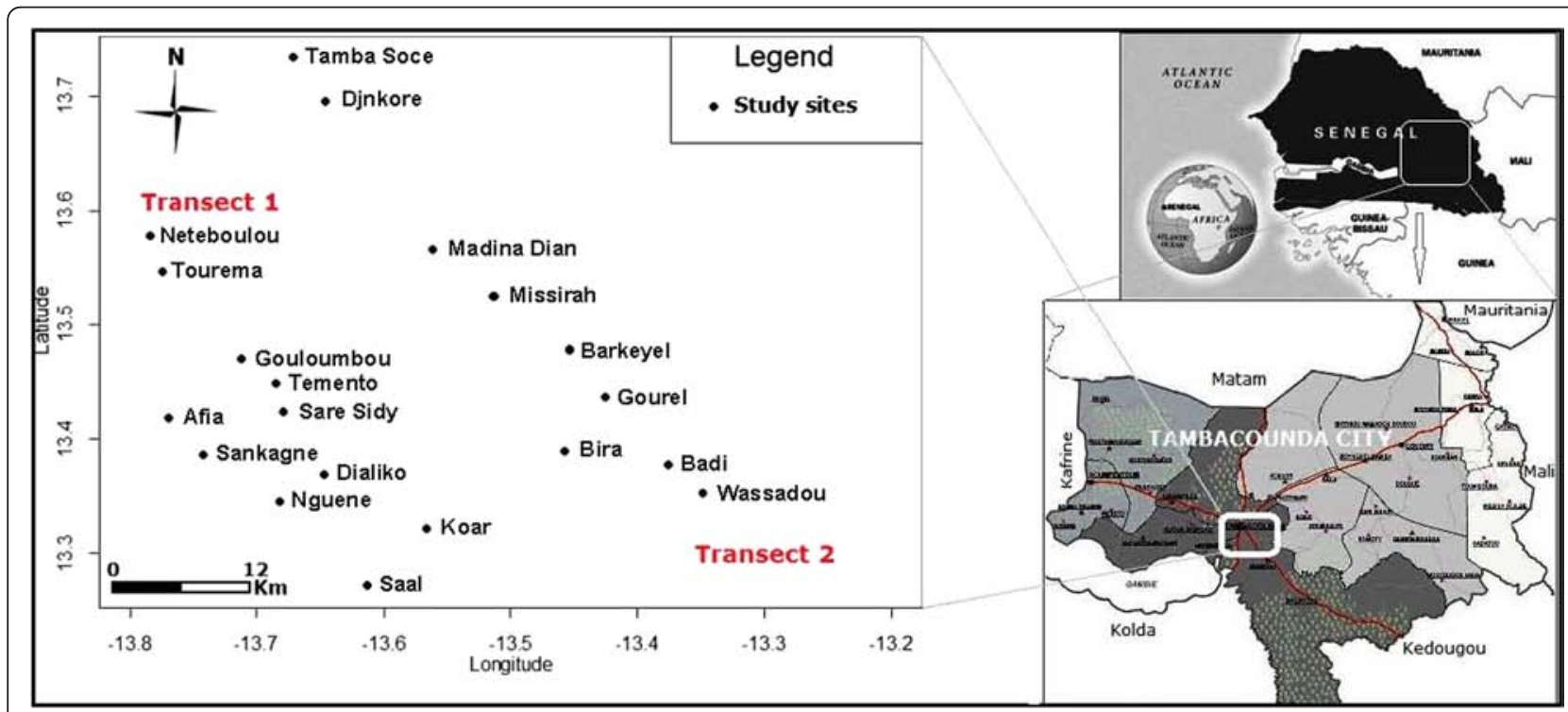

Fig. 1 Localisation of the study sites 
peak in August-September, and an annual rainfall of $500 \mathrm{~mm}$.

In 2010, 20 sites were selected from two distinct transects. The first is situated along the Gambia River an agricultural areas growing rice and cash crops of banana with high pesticide usage. The second transect is along the National Road 7, in a less humid and mostly arid area with a little or no application of pesticides. In each site, indoor resting mosquitoes were collected during the daytime using pyrethrum sprays. Upon collection, mosquitoes were counted and identified as An. gambiae s.l. morphologically using the keys of Gillies \& de Meillon [20]. All the mosquito samples were stored individually after identification in numbered vials containing desiccant until laboratory processing.

In 2011, Anopheles larvae and pupae were collected from natural breeding sites in four selected sites (two in the first transect namely Koar and Sankagne and two in the second transect namely Djnkore and Wassadou). Upon collection, they were kept in separate labelled bottles, transported to the insectary and maintained at a relative humidity of $75 \pm 5 \%$ and a temperature of $28 \pm 3{ }^{\circ} \mathrm{C}$.

\section{$k d r$ molecular genotyping and species identification}

For molecular identification, genomic DNA was extracted from the wings or legs of individual mosquitoes as described by Collins et al. [21]. For each collection of mosquitoes randomly sampled from each village, 30-100\% of females belonging to the An. gambiae s.l. were identified to species using the molecular methods of Favia et al. [22] and Fanello et al. [23]. The presence of L1014F mutation was confirmed using the method described by MartinezTorres et al. [5].

\section{Insecticide susceptibility tests}

Insecticide susceptibility tests were conducted on unfed adult females aged from 2 to 5 days. Bioassays were carried out using WHO test kits for adult mosquitoes. Insecticideimpregnated papers were provided by The Vector Control Research Unit, School of Biological Sciences (Universiti Sains Malaysia), a WHO Collaborating Centre. The following diagnostic concentrations of insecticides were tested: $0.05 \%$ deltamethrin, $4 \%$ DDT, $0.75 \%$ permethrin, $0.05 \%$ lambdacyhalothrin, $5 \%$ malathion and $0.1 \%$ bendiocarb. For each insecticide, four replicates were exposed for $60 \mathrm{~min}$. The mosquitoes were then transferred in tubes with untreated papers and kept under observation for $24 \mathrm{~h}$.

\section{Data analysis}

The $k d r$ allele frequency was estimated for each site and period of collection as the proportion of specimens found with the L1014F $k d r$ alleles. The frequencies as well as the conformity to Hardy-Weinberg equilibrium were assessed using Genepop v.3.2. [24].

For each insecticide, the resistance status was studied using WHO criteria [1]. For DDT and pyrethroid insecticides, knock-down rates (\%) were assessed at 10, 15, 20, 30, 40, 50 and $60 \mathrm{~min}$.

All statistical analyses were performed using $\mathrm{R}$ software (version 3.0.2).

\section{Results}

Frequency and distribution of 1014F allele

In this study, the $k d r$ mutation was confirmed in $A n$. gambiae s.l. populations in all of the 20 sites selected (frequency range $0.05-0.33 \%$ ) with significant variations $\left(\mathrm{X}^{2}=76.3, \mathrm{df}=19, p<0.001\right)$. Examination of $189 \mathrm{An}$. arabiensis, 115 An. coluzzii and 814 An. gambiae showed that only $A n$. gambiae s.s. was carrying the $k d r$ mutation in all the 20 sites (frequency range: $0.06-0.38 \%$ ). The $k d r$ mutation was observed in 17 sites (frequency range in observed sites: $0.04-0.40 \%$ ) and 12 sites (frequency range in observed sites: $0.06-0.50 \%)$ in An. arabiensis and $A n$. coluzzii, respectively (Table 1 , Fig. 2). The mean $k d r$ frequencies by species were $14.38 \pm 2.42$ (An. arabiensis), $21.22 \pm 3.85$ (An. gambiae) and $14.69 \pm 1.95$ (An. coluzzii). No significant differences were observed between these means (one-way ANOVA, $\mathrm{F}=1.83, p=0.17$ ).

These frequencies were significantly different only between $A n$. gambiae and An. arabiensis ( $\mathrm{X}^{2}=10.92, \mathrm{df}=1$, $p=0.0009)$, irrespective of the transects. When considering each species within each different transect, the prevalence of the 1014F $k d r$ allele was similar between all three species in each transect. In $A n$. coluzzii, the $1014 \mathrm{~F} k d r$ allele was the only allele observed in two of the nine localities prospected in transect two (Madina Dian and Bira) .

\section{Mortality rates}

In all the bioassays, controls using wild An. gambiae s.l. populations from each site showed mortality rate less than $5 \%$, thus, no corrections were required in the test sample data.

All populations exhibited resistance to DDT (Fig. 3). The highest mortality rate was observed for Djnkore populations (mortality rate $=74.07 \%$, IC95 $=64.75-82.03 \%$ ). For pyrethroids, resistance was observed for both types: Type I (permethrin) and Type II (deltamethrin, lambdacyhalothrin) for all populations except in Sankagne (deltamethrin) and probably in Wassadou (permethrin) and Koar (lambdacyhalothrin) where a probable resistance is observed with the mortality rates of $94 \%$ (IC95 $=87.4-97.77 \%$ ) and $94.12 \%$ (IC95=87.64-97.81\%) for the two latter villages. Full susceptibility was observed for the organophosphate malathion (Koar and Sankagne) and for the carbamate bendiocarb (Koar, Sankagne and 
Table 1 Frequencies of the L1014F kdr allele within the 20 sites prospected

\begin{tabular}{|c|c|c|c|c|c|c|c|c|c|c|c|c|c|}
\hline \multirow[t]{2}{*}{ Transects } & \multirow[t]{2}{*}{ Sites } & \multicolumn{4}{|c|}{ An. arabiensis } & \multicolumn{4}{|c|}{ An. gambiae } & \multicolumn{4}{|c|}{ An. coluzzii } \\
\hline & & $n$ & Fis & Freq & $95 \%$ Cl & $n$ & Fis & Freq & $95 \%$ Cl & $n$ & Fis & Freq & $95 \% \mathrm{Cl}$ \\
\hline \multirow[t]{11}{*}{ Transect 1} & Neteboulou & 23 & -0.05 & 0.04 & $0.01-0.15$ & 30 & -0.25 & 0.20 & $0.11-0.32$ & 4 & -0.14 & 0.13 & $0.00-0.53$ \\
\hline & Tourema & 13 & 0.80 & 0.27 & $0.12-0.48$ & 21 & 0.80 & 0.38 & $0.24-0.54$ & 1 & 0 & 0.00 & $0.00-0.54$ \\
\hline & Gouloumbou & 57 & 0.65 & 0.15 & $0.09-0.23$ & 76 & 0.50 & 0.22 & $0.15-0.29$ & 13 & 0.84 & 0.42 & $0.23-0.63$ \\
\hline & Afia & 32 & 0.63 & 0.09 & $0.04-0.19$ & 35 & 0.03 & 0.16 & $0.08-0.26$ & 3 & -0.5 & 0.33 & $0.04-0.78$ \\
\hline & Temento & 13 & -0.13 & 0.12 & $0.02-0.30$ & 27 & -0.2 & 0.28 & $0.16-0.42$ & 0 & 0 & 0.00 & - \\
\hline & Sare Sidy & 20 & 0.43 & 0.33 & $0.19-0.49$ & 38 & 0.42 & 0.20 & $0.11-0.30$ & 1 & 0 & 0.00 & $0.00-0.84$ \\
\hline & Sankagne & 21 & 0.32 & 0.12 & $0.04-0.26$ & 23 & 0.40 & 0.24 & $0.13-0.39$ & 7 & 1 & 0.14 & $0.02-0.43$ \\
\hline & Nguene & 29 & 0.58 & 0.21 & $0.11-0.33$ & 40 & 0.12 & 0.11 & $0.05-0.20$ & 8 & 1 & 0.13 & $0.02-0.38$ \\
\hline & Dialiko & 19 & 0.59 & 0.24 & $0.11-0.40$ & 45 & 0.17 & 0.20 & $0.12-0.30$ & 9 & -0.06 & 0.06 & $0.00-0.27$ \\
\hline & Koar & 44 & 0.37 & 0.15 & $0.08-0.24$ & 103 & 0.38 & 0.25 & $0.19-0.32$ & 20 & 0.69 & 0.20 & $0.09-0.36$ \\
\hline & Saal & 10 & -0.05 & 0.05 & $0.00-0.25$ & 34 & 0.47 & 0.06 & $0.02-0.14$ & 8 & 0 & 0.00 & $0.00-0.21$ \\
\hline \multirow[t]{9}{*}{ Transect 2} & Tamba Soce & 19 & - & 0.00 & $0.00-0.09$ & 14 & 0.76 & 0.18 & $0.06-0.37$ & 0 & 0 & 0.00 & - \\
\hline & Djnkore & 42 & 0.45 & 0.10 & $0.04-0.18$ & 65 & 0.61 & 0.20 & $0.14-0.28$ & 2 & -0.33 & 0.25 & $0.01-0.81$ \\
\hline & Madina Dian & 20 & 0.79 & 0.4 & $0.25-0.57$ & 17 & 0.76 & 0.15 & $0.05-0.31$ & 2 & 1 & 0.50 & $0.07-0.93$ \\
\hline & Missirah & 5 & - & 0.00 & $0.00-0.31$ & 4 & 0.47 & 0.38 & $0.09-0.76$ & 0 & 0 & 0.00 & - \\
\hline & Barkeyel & 27 & 1 & 0.15 & $0.07-0.27$ & 22 & 0.74 & 0.23 & $0.11-0.38$ & 2 & 0 & 0.00 & - \\
\hline & Gourel & 6 & - & 0.00 & $0.00-0.26$ & 59 & 0.11 & 0.14 & $0.09-0.22$ & 4 & 0 & 0.00 & - \\
\hline & Bira & 13 & 0.13 & 0.23 & $0.09-0.44$ & 30 & 0.05 & 0.35 & $0.23-0.48$ & 2 & 0 & 0.50 & $0.07-0.93$ \\
\hline & Badi & 41 & 0.54 & 0.12 & $0.06-0.21$ & 56 & 0.12 & 0.09 & $0.04-0.16$ & 24 & 0.45 & 0.08 & $0.02-0.20$ \\
\hline & Wassadou & 16 & 0.63 & 0.13 & $0.04-0.29$ & 75 & -0.02 & 0.24 & $0.17-0.32$ & 5 & -0.25 & 0.20 & $0.03-0.56$ \\
\hline
\end{tabular}

$n$ number of specimens, $F_{\text {is }}$ : inbreeding coefficient calculated according to Weir and Cockerham [40], $F_{\text {is }}<0$ indicate an excess of heterozygotes, $F_{\text {is }}>0$ denote heterozygotes deficiency, values in bold indicate significant deviation from Hardy-Weinberg $(P<0.05)$

Djnkore). Wassadou populations exhibited resistance to bendiocarb with a mortality rate of $95.87 \%$ (IC95 = 90.62-98.64\%).

Although a statistically significant difference was observed between mortality rates for sites showing confirmed resistance for DDT $\left(\mathrm{x}^{2}=22.3, \mathrm{df}=3, p<0.001\right)$, no significant differences were observed for deltamethrin and permethrin, whereas mortality rates to lambdacyhalothrin were significantly different between Sankagne and Dinkore $\left(\chi^{2}=4.4, \mathrm{df}=1, p=0.03\right)$.

\section{Knock down effects of pyrethroids}

Despite the resistant status observed, the study of the knock down effects of DDT and pyrethroids showed different patterns. For DDT, the resistance observed was associated to a low effect on the four populations tested (Fig. 4). Indeed after 60 min exposure the highest knock down effect was below 75 \% (population from Djnkore). For the other populations, the highest values were respectively 57.01, 53.43 and $31.35 \%$ at $60 \mathrm{mn}$ for Koar, Sankagne and Wassadou (Fig. 4). For these populations,
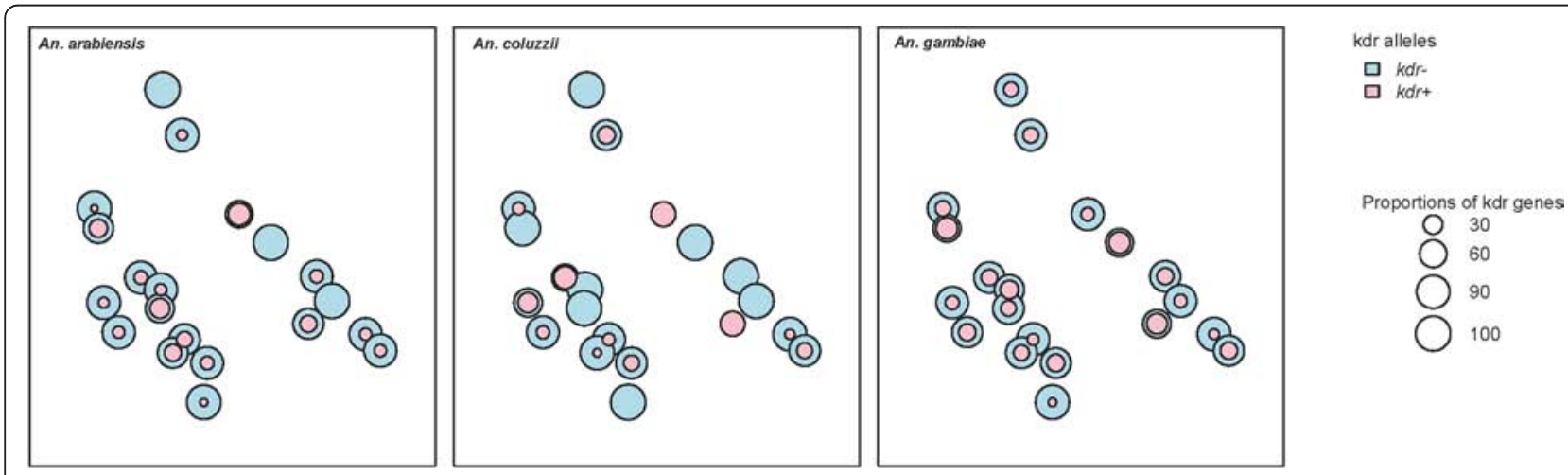

Fig. 2 Spatial variations of the L1014F kdr allele in An. arabiensis, An. coluzzii and An. gambiae in the 20 sites prospected 


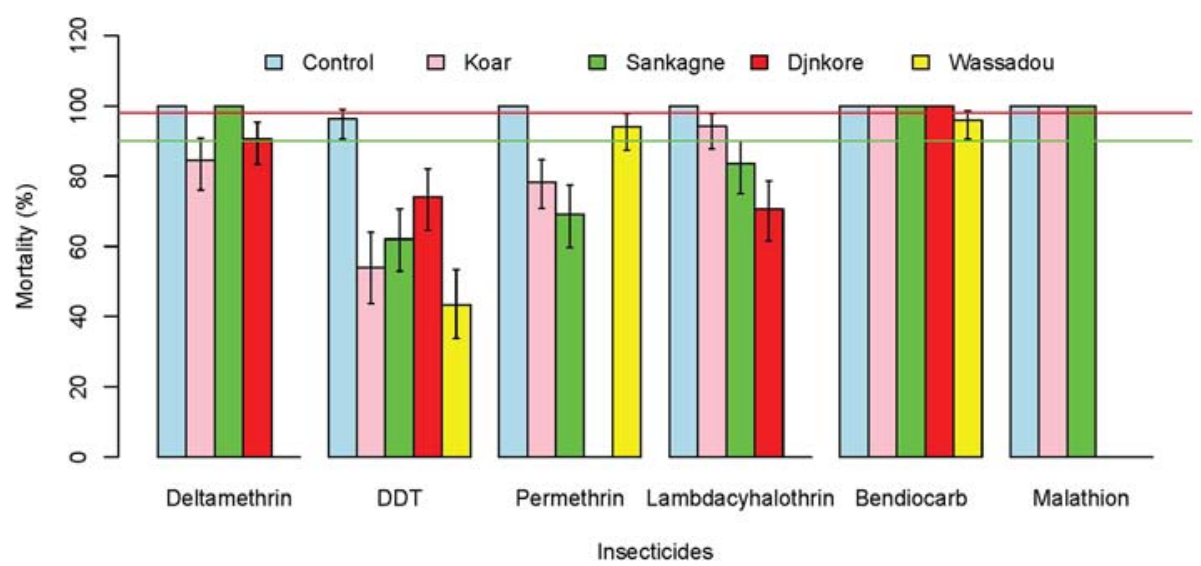

Fig. 3 Mortalities observed with the six insecticides tested for the four populations. The green and red lines indicate respectively the 90 and $98 \%$ limits

KD50 and KD95 increased markedly with a near complete loss of knock down effect for the Wassadou population (Table 2). Despite the resistance status observed for Koar, a similar trend of the KD rates was observed for deltamethrin in Sankagne $(p<0.05)$ with $100 \%$ knock down at 20 min (Fig. 5). For lambdacyhalothrin, the KD dynamics were quite similar for Koar, Sankagne and Djnkore populations (Fig. 6). While the KD50 times were similar, a slight increase of the KD95 was observed in the resistant population of Djnkore, but no significant difference was observed with the populations of Koar and Sankagne $(p<0.05$ after Bonferroni correction). For permethrin, the pattern of KD effect is similar to the resistance status (Fig. 7). Whatever the population pairs considered, the difference was statistically significant $(p<0.05)$.

\section{Discussion}

The present study compared the patterns of insecticide resistance and $k d r$ resistance in three sympatric species of the An. gambiae complex. The study of the distribution of the L1014F $k d r$ mutation showed its widespread presence in the study sites particularly in An. gambiae in comparison to An. arabiensis and An. coluzzii as observed elsewhere in Africa [7, 8, 25]. In Senegal, previous reports have documented the presence of the L1014F $k d r$ allele in $A n$. gambiae populations from the southeastern part of the country with frequencies ranging from 14.1 to $18.6 \%$ [26] and in An. arabiensis populations from two suburbs of Dakar [27]. Compared to the present study, these observed frequencies are low with respect to some of our sites herein, where the L1014F

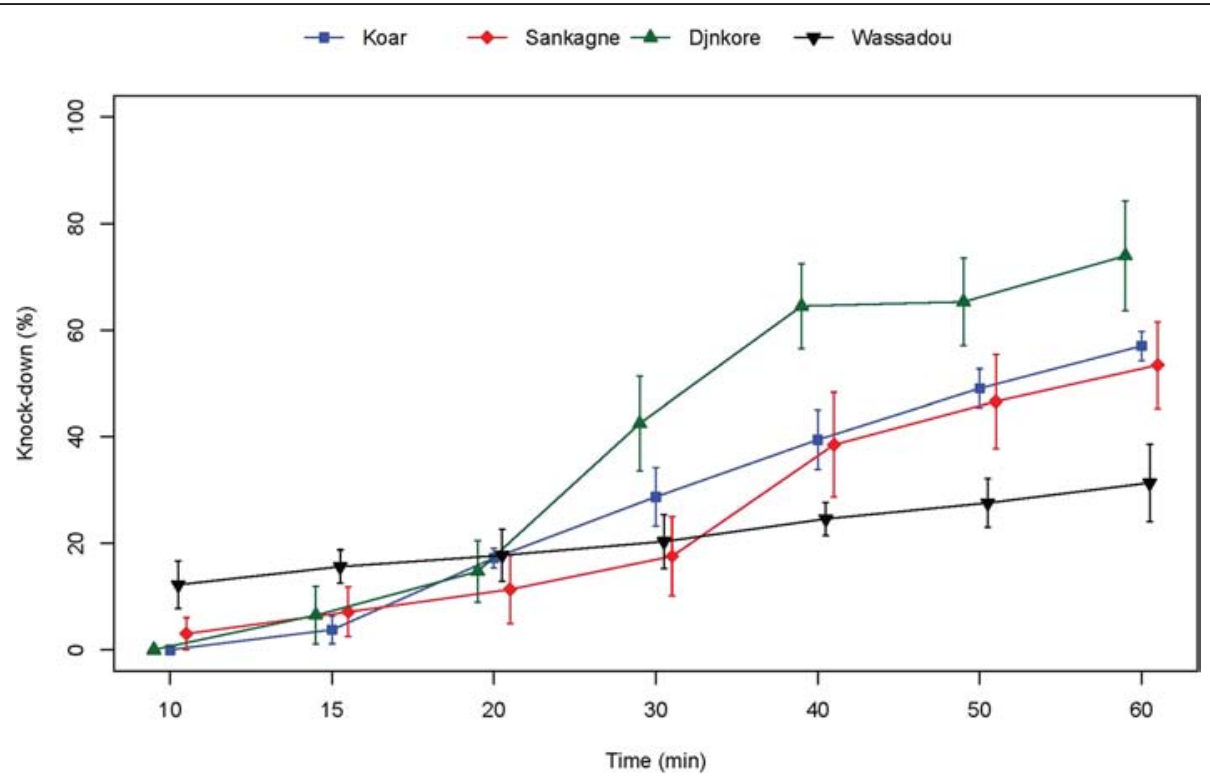

Fig. 4 Evolution of the knock-down rates of mosquitoes due to exposure to DDT 
Table 2 Observed knock-down for DDT and the pyrethroids tested

\begin{tabular}{|c|c|c|c|c|c|c|}
\hline Insecticides & & Djnkore & Koar & Sankagne & Wassadou & Control strain \\
\hline \multirow[t]{5}{*}{ DDT } & Number tested & 108 & 100 & 124 & 106 & 106 \\
\hline & KD50 (min) & 34.57 & 49.52 & 52.37 & no kd & 20.06 \\
\hline & & $(31.05-38.71)$ & $(44.93-55.51)$ & $(43.94-68.50)$ & & $(18.25-21.98)$ \\
\hline & KD95 (min) & 90.54 & 174.86 & 197.56 & no kd & 35.13 \\
\hline & & $(73.57-123.55)$ & (136.28-247.58) & $(126.78-458.52)$ & & $(30.81-42.71)$ \\
\hline \multirow[t]{5}{*}{ deltamethrin } & Number tested & 106 & 103 & 107 & & 103 \\
\hline & KD50 (min) & 7.79 & 10.28 & 9.93 & - & 10.93 \\
\hline & & $(1.59-12.69)$ & $(9.71-10.77)$ & $(9.31-10.43)$ & & $(10.26-11.53)$ \\
\hline & KD95 (min) & 73.27 & 14.71 & 14.43 & - & 17.25 \\
\hline & & $(43.77-403.87)$ & $(13.72-16.34)$ & $(13.45-16.12)$ & & $(16.00-19.17)$ \\
\hline \multirow[t]{5}{*}{ lambdacyhalothrin } & Number tested & 119 & 102 & 103 & & 101 \\
\hline & KD50 (min) & 21.42 & 19.12 & 20.19 & - & 16.63 \\
\hline & & (16.39-26.46) & $(17.14-21.16)$ & $(18.01-22.37)$ & & $(15.90-17.42)$ \\
\hline & KD95 (min) & 85.91 & 38.41 & 55.10 & - & 20.20 \\
\hline & & $(59.22-181.26)$ & (33.16-47.55) & (46.79-69.03) & & $(19.00-22.47)$ \\
\hline \multirow[t]{5}{*}{ permethrin } & Number tested & - & 147 & 113 & 100 & 102 \\
\hline & KD50 (min) & - & 31.89 & 55.61 & 7.35 & 9.05 \\
\hline & & & (25.28-41.89) & $(49.46-65.29)$ & $(0.09-14.00)$ & - \\
\hline & KD95 (min) & - & 194.85 & 164.88 & 138.15 & 10.33 \\
\hline & & & (109.60-698.53) & $(123.03-262.62)$ & $\left(59.42-76.10^{3}\right)$ & - \\
\hline
\end{tabular}

$k d r$ mutation frequencies were up to $38 \%$ in An. gambiae, $50 \%$ in An. coluzzii and $40 \%$ in An. arabiensis. However, these frequencies seem to be low when compared with other sites in Benin where frequencies of up to $80 \%$ were recently observed [28]. The comparison of the observed frequencies with those expected under
Hardy-Weinberg equilibrium indicated in some cases (mainly in $A n$. gambiae and An. arabiensis populations), a deficit or excess of heterozygotes. While the origin of the L1014F mutation in An. arabiensis is suspected to be a new and independent mutation, its presence in $A n$. coluzzii has been suggested to occur by introgression

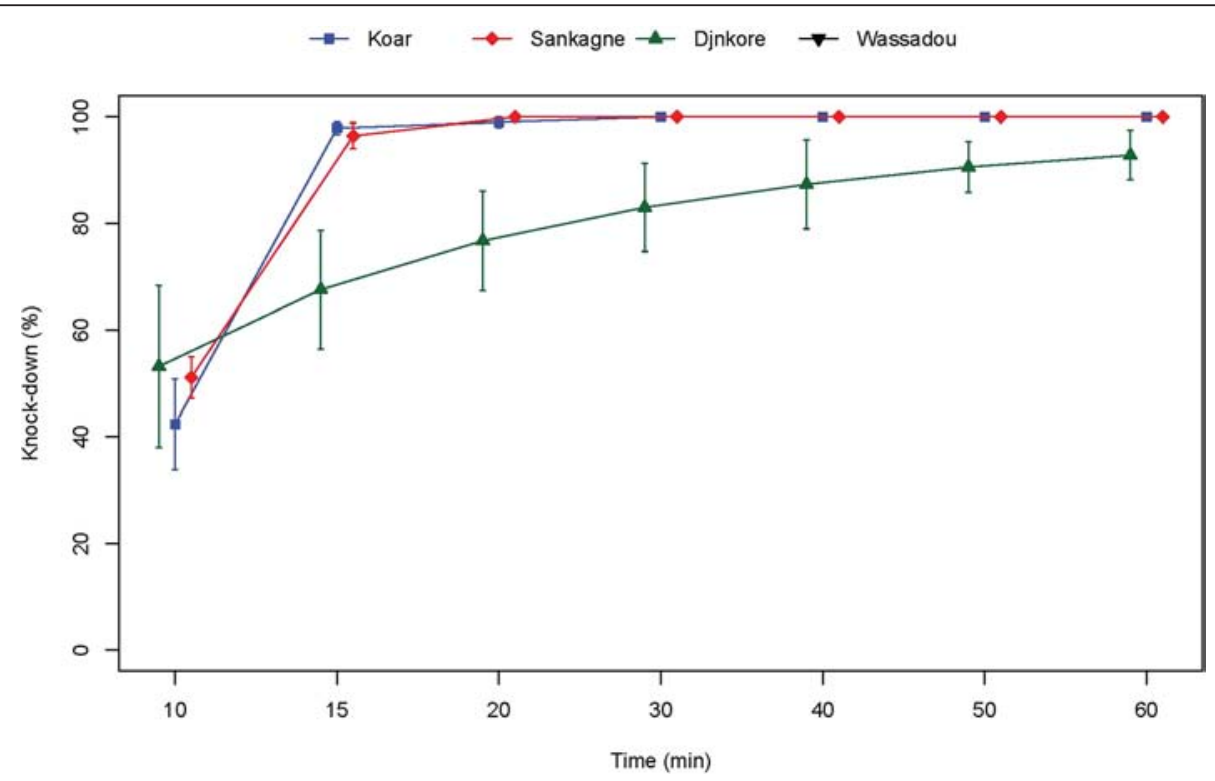

Fig. 5 Evolution of the knock-down rates of mosquitoes due to exposure to deltamethrin 


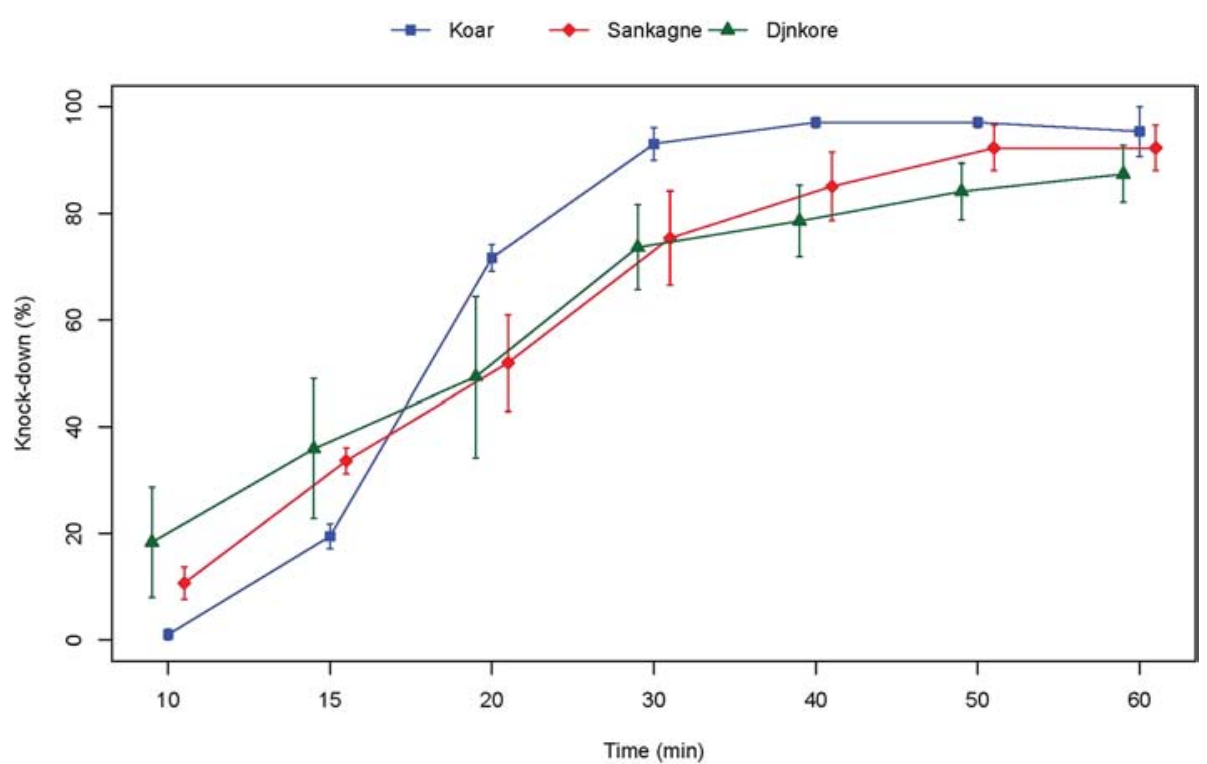

Fig. 6 Evolution of the knock-down rates of mosquitoes due to exposure to lambdacyhalothrin

from An. gambiae [29]. Therefore, it is undoubtedly important to carry out additional studies to unravel the origin of this mutation in An. arabiensis and An. coluzzii in our context as other mechanisms could be involved.

Globally, the results of the bioassay tests showed that the populations were resistant to DDT and pyrethroids and susceptible to organophosphate and carbamate. This situation is relatively common in many sites in Africa [30]. In West Africa, pyrethroid resistance is high, widespread and predominant in An. gambiae compared to $A n$. arabiensis [8]. Concerning carbamate and organophospahe insecticides, our results contrast with recent findings that showed high levels of resistance to these insecticides in the urban site of Dakar [31].

The resistance levels observed to pyrethroids varied greatly between the four sites studied. For deltamethrin and permethrin the lack of difference in mortality rates could reflect no differential selection pressures on malaria vectors. This could be due to the fact that these insecticides are the most widely used in insecticides-treated nets distributed by the National Malaria Control Program in Senegal. Indeed, Senegal is on the short list of African countries that have reached the RBM target of $80 \%$ of households owning at least one insecticide-treated nets

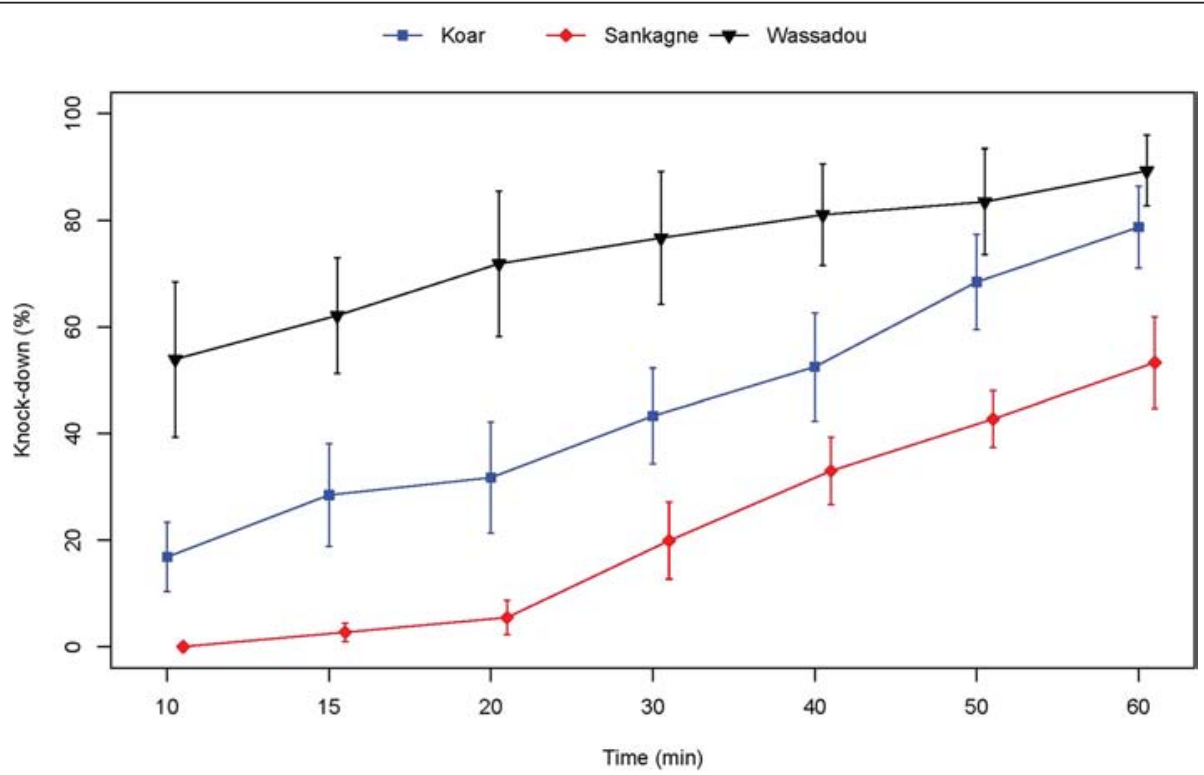

Fig. 7 Evolution of the knock-down rates of mosquitoes due to exposure to permethrin 
[32]. Despite the resistance observed, the study of the KD dynamic showed a similar effect of deltamethrin on the resistant population of Koar compared to the susceptible population of Sankagne where a similar trend was observed. In contrast, the study of the effect of permethrin showed profiles similar to observed resistance. Except the fact that deltamethrin and permethrin are different chemical molecules (type I vs type II), this observation may express a more recent use of deltamethrin in the area in comparison with permethrin. Indeed, impregnated-bednets (Olyset Net@) were introduced in the study area in the 1990's [33] and could have exerted strong insecticidal pressures on mosquitoes giving rise to the high levels of insecticide resistance observed. However, for lambdacyhalothrin, the difference observed between Koar and Djnkore reflects variation in resistance selection pressures, which results from differential use in agriculture representing the main human activities.

\section{Conclusions}

During this study a widespread resistance to DDT and pyrethroids and a widespread $1014 \mathrm{~F} k d r$ allele distribution was observed. The observed resistance to DDT and pyrethroids combined with the high KD times could suggest the involvement of the $1014 \mathrm{~F} k d r$ mutation, as observed elsewhere [34-37]. However, the involvement of other resistance mechanisms including the $1014 \mathrm{~S}$ $k d r$ mutation recently observed in West Africa and Senegal [31, 38, 39], could not be ruled out, as at least $50 \%$ of the populations did not harbour the 1014F allele whereas the populations were fully resistant. This needs further investigations. The susceptibility to carbamate and organophosphate could be an alternative for insecticide resistance management.

\section{Competing interests}

The authors declare that they have no competing interests.

\section{Authors' contributions}

ID, EAN, MD conceived and designed the study. EAN and ID carried out the field collections, performed the experiments and analysed the data. EAN, LK, OF, MD and ID drafted the manuscript and read, critically revised and approved the final manuscript

\section{Acknowledgements}

This study was funded by the EU project INFRAVEC (Research capacity for the implementation of genetic control of Mosquitoes) and the European Commission's Seventh Framework Research Programme under the grant agreement 228421).

\section{Author details}

'Unité d'Entomologie Médicale, Institut Pasteur de Dakar, 36 Avenue Pasteur, BP 220, Dakar, Sénégal. 'Laboratoire d’Ecologie Vectorielle et Parasitaire, Université Cheikh Anta Diop de Dakar, Dakar, Sénégal.

Received: 9 September 2015 Accepted: 30 January 2016

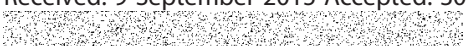

\section{References}

1. WHO. Test procedures for insecticide resistance monitoring in malaria vector mosquitoes. Geneva: World Health Organization; 2013

2. Curtis CF, Mnzava AE, Misra S, Rowland M. Bednets or spraying? Summary of the presentations and the discussion. Trans R Soc Trop Med Hyg. 1999:93:460.

3. Nyarango PM, Gebremeskel T, Mebrahtu G, Mufunda J, Abdulmumini U, Ogbamariam A, et al. A steep decline of malaria morbidity and mortality trends in Eritrea between 2000 and 2004: the effect of combination of control methods. Malar J. 2006;5:33.

4. WHO. Indoor residual spraying. An operational manual for indoor residual spraying (IRS) for malaria transmission control and elimination. Geneva: World Health Organization; 2013.

5. Martinez-Torres D, Chandre F, Williamson MS, Darriet F, Berge JB, Devonshire AL, et al. Molecular characterization of pyrethroid knockdown resistance $(k d r)$ in the major malaria vector Anopheles gambiae s.s. Insect Mol Biol. 1998:7:179-84.

6. Ranson H, Jensen B, Vulule JM, Wang X, Hemingway J, Collins FH. Identification of a point mutation in the voltage-gated sodium channel gene of Kenyan Anopheles gambiae associated with resistance to DDT and pyrethroids. Insect Mol Biol. 2000;9:491-7.

7. Ranson H, N'Guessan R, Lines J, Moiroux N, Nkuni Z, Corbel V. Pyrethroid resistance in African anopheline mosquitoes: what are the implications for malaria control? Trends Parasitol. 2011;27:91-8.

8. Corbel V, N'Guessan R. Distribution, mechanisms, impact and management of insecticide resistance in malaria vectors. A pragmatic review. Edited by Manguin S. Rijeka, Croatia: In Tech Publisher; 2013. p. 579-633.

9. Neafsey DE, Lawniczak MK, Park DJ, Redmond SN, Coulibaly MB, Traore SF, et al. SNP genotypying defines complex gene-flow boundaries among African malaria vector mosquitoes. Science. 2010;330:514-7.

10. Reidenbach KR, Neafsey DE, Costantini C, Sagnon NF, Simard F, Ragland GJ, et al. Patterns of genomic differentiation between ecologically differentiated $\mathrm{M}$ and $\mathrm{S}$ forms of An. gambiae in West and Central Africa. Genome Biol Evol. 2012:4:1202-12.

11. Coetzee M, Hunt RH, Wilkerson R, della Torre A, Coulibaly MB, Besansky NJ. Anopheles coluzzii and Anopheles amharicus, new members of the Anopheles gambiae complex. Zootaxa. 2013;3:246-74.

12. Nwakanma DC, Neafsey DE, Jawara M, Adiamoh M, Lund E, Rodrigues A, et al. Breakdown in the Process of Incipient Speciation in Anopheles gambiae. Genetics. 2013;193:1221-31.

13. Niang EA, Konaté L, Diallo M, Faye O, Dia I. Reproductive Isolation among Sympatric Molecular Forms of An. gambiae from Inland Areas of South-Eastern Senegal. PLoS One. 2014;9:e104622.

14. della Torre A, Fanello C, Akogbeto M, Dossou-Yovo J, Favia G, Petrarca V, et al. Molecular evidence of incipient speciation within Anopheles gambiae s.s. in West Africa. Insect Mol Biol. 2001;10:9-18.

15. Wondji CS, Simard F, Fontenille D. Evidence for genetic differentiation between the molecular forms $\mathrm{M}$ and $\mathrm{S}$ within the Forest chromosomal form of Anopheles gambiae in an area of sympatry. Insect Mol Biol. 2002:11:11-9.

16. Fanello C, Petrarca V, della Torre A, Santolamazza F, Dolo G, Coulibaly M, et al. The pyrethroid knock-down resistance in the Anopheles gambiae complex in Mali and further indication of incipient speciation within An. gambiae s.s. Insect Mol Biol. 2003:12:241-5.

17. Awolola TS, Oyewole IO, Amajoh CN, Idowu ET, Ajayi MB, Oduola A, et al. Distribution of the molecular forms of Anopheles gambiae and pyrethroid knock down resistance gene in Nigeria. Acta Trop. 2005;95:204-9.

18. Weill M, Chandre F, Brengues C, Manguin S, Akogbeto M, Pasteur N, et al. The $k d r$ mutation occurs in the Mopti form of Anopheles gambiae s.s. through introgression. Insect Mol Biol. 2000;9:451-5.

19. Etang J, Vicente JL, Nwane P, Chouaibou M, Morlais I, Do Rosario VE, et al. Polymorphism of intron-1 in the voltage-gated sodium channel gene of Anopheles gambiae s.s. populations from Cameroon with emphasis on insecticide knockdown resistance mutations. Mol Ecol. 2009;18:3076-86.

20. Gillies MT, de Meillon B. The anophelinae of Africa, south of the Sahara. Johannesburg The South African Institute for Medical Research. 1068; 54: 343 pages.

21. Collins FH, Mendez MA, Rasmussen MO, Mehaffey PC, Besansky NJ, Finnerty $\checkmark$. A ribosomal RNA gene probe differentiates member species of the Anopheles gambiae complex. Am J Trop Med Hyg. 1987;37:37-41.

22. Favia G, della Torre A, Bagayoko M, Lanfrancotti A, Sagnon N, Toure YT. Molecular identification of sympatric chromosomal forms of Anopheles 
gambiae and further evidence of their reproductive isolation. Insect Mol Biol. 1997:6:377-83

23. Fanello C, Santolamazza F, della Torre A. Simultaneous identification of species and molecular forms of the Anopheles gambiae complex by PCR-RFLP. Med Vet Entomol. 2002;16:461-4.

24. Raymond M, Rousset F. GENEPOP Version 1.2. A population genetics software for exact tests and ecumenicism. J Hered. 1995;86:248-9.

25. Dabire RK, Namountougou M, Diabate A, Soma DD, Bado J, Hyacinthe K, et al. Distribution and Frequency of kdr Mutations within Anopheles gambiae s.l. Populations and First Report of the Ace.1G1 195 Mutation in Anopheles arabiensis from Burkina Faso (West Africa). PLoS One. 2014;9:e101484.

26. Santolamazza F, Calzetta M, Etang J, Barrese E, Dia I, Caccone A, et al. Distribution of the knock-down resistance mutations in Anopheles gambiae molecular forms in west and west-central Africa. Malaria J. 2008;7:74.

27. Pagès F, Texier G, Pradines B, Gadiaga L, Machault V, Jarjaval F, et al. Malaria transmission in Dakar: A two-year survey. Malaria J. 2008;7:178.

28. Gnanguenon V, Agossa FR, Badirou K, Govoetchan R, Anagonou R, OkeAgbo F, et al. Malaria vectors resistance to insecticides in Benin: current trends and mechanisms involved. Parasit Vectors. 2015;8:223.

29. Diabate A, Brengues C, Baldet T, Dabire KR, Hougard JM, Akogbeto M, et al. The spread of the Leu-Phe kdr mutation through Anopheles gambiae complex in Burkina Faso: genetic introgression and de novo phenomena. Trop Med Int Health. 2004;9:1267-73.

30. Chandre F, Darriet F, Manga L, Akogbeto M, Faye O, Mouchet J, et al. Status of pyrethroid resistance in Anopheles gambiae sensu lato. Bull World Health Organ. 1999:77:230-4.

31. Ndiath MO, Cailleau A, Orlandi-Pradines E, Bessell P, Pagès F, Trape JF, et al. Emerging knock-down resistance in Anopheles arabiensis populations of Dakar, Senegal: first evidence of a high prevalence of kdr-e mutation in West African urban area. Malar J. 2015;14(1):364.

32. Thwing Jl, Perry RT, Townes DA, Diouf MB, Ndiaye S, Thior M. Success of Senegal's first nationwide distribution of long-lasting insecticide-treated nets to children under five - contribution toward universal coverage. Malaria J. 2011;10:86

33. Faye O, Konaté L, Gaye O, Fontenille D, Sy N, Diop A, et al. Impact de I'utilisation des moustiquaires pré-imprégnées de perméthrine sur la transmission du paludisme dans un village hyperendémique du Sénégal. Med Trop. 1998;58:355-60.

34. Tia E, Akogbeto M, Koffi A, Toure M, Adja AM, Koné M, et al. Situation de la résistance d'Anopheles gambiae s.s. (Diptera : Culicidae) aux pyréthrinoïdes et au DDT dans cinq écosystèmes agricoles de Côte-d'Ivoire. Bull Soc Pathol Exot. 2006;99:278-82

35. Dabiré KR, Diabaté A, Namountougou M, Toé KH, Ouari A, Kengne P, et al. Distribution of pyrethroid and DDT resistance and the L1014F kdr mutation in Anopheles gambiae s.l. from Burkina Faso (West Africa). Trans R Soc Trop Med Hyg. 2009;103:1113-20.

36. Kwiatkowska RM, Platt N, Poupardin R, Irving H, Dabire RK, Mitchell S, et al. Dissecting the mechanisms responsible for the multiple insecticide resistance phenotype in Anopheles gambiae s.s. M form, from Vallée du Kou. Burkina Faso. Gene. 2013:519:98-106.

37. Okorie PN, Ademowo OG, Irving H, Kelly-Hope LA, Wondji CS. Insecticide susceptibility of Anopheles coluzzii and Anopheles gambiae mosquitoes in Ibadan, Southwest Nigeria. Med Vet Entomol. 2015;29:44-50.

38. Djegbe I, Boussari O, Sidick A, Martin T, Ranson H, Chandre F, et al. Dynamics of insecticide resistance in malaria vectors in Benin: first evidence of the presence of L1014S kdr mutation in Anopheles gambiae from West Africa. Malar J. 2011;10:261.

39. Badolo A, Traore A, Jones CM, Sanou A, Flood L, Guelbeogo WM, et al. Three years of insecticide resistance monitoring in Anopheles gambiae in Burkina Faso: resistance on the rise? Malar J. 2012;11:232.

40. Weir BS, Cockerham CC. Estimating F-statistics for the analysis of population structure. Evolution. 1984;38:1358-70.

\section{Submit your next manuscript to BioMed Central and we will help you at every step:}

- We accept pre-submission inquiries

- Our selector tool helps you to find the most relevant journal

- We provide round the clock customer support

- Convenient online submission

- Thorough peer review

- Inclusion in PubMed and all major indexing services

- Maximum visibility for your research

Submit your manuscript at www.biomedcentral.com/submit
Biomed Central 